\title{
Collaborative training to improve beef cattle farmers' technical competency in West Pasaman District
}

\author{
Fuad Madarisa $^{a^{*}}$, Melinda Noer ${ }^{b}$, Asmawic, and Jafrinur ${ }^{d}$. \\ ${ }^{a}$ Department of Agricultural Development, Postgraduate program of the Andalas University, Padang, Indonesia,25163. \\ ${ }^{b}$ Department of Participative Development Planning, Agricultural Faculty, Andalas University Padang, Indonesia, 25163. \\ ${ }^{c}$ Department of Communication, Faculty of Social and Political Science, Andalas University Padang, Indonesia, 25163. \\ ${ }^{d}$ Department of Business and Development, Faculty of Animal Science, the Andalas University Padang, Indonesia, 25163.
}

A R T I CLE INFO

Article history:

Received 13 October 2016

Revised 17 January 2017

Accepted 2 February 2017

Keywords:

Beef cattle farmers

Breeding program

Collaboration

Training

\begin{abstract}
A B S T R A C T
At the end of 2015, this study has been conducted to describe the planning; process; and evaluation of collaborative training using a comparative approach, 220 and 44 beef cattle farmers participated as informant in both types of - collaborative and non-collaborative training respectively. Fifteen informants representing stakeholder provided primary data. Both primary and secondary data were analyzed by using qualitative and quantitative approaches. The results showed that planning was based on an effort to accomplish the discrepancy of cattle farmer technical competency to perform breeding program. Process of conducting collaborative training focused on group management and keeping beef cattle. In non-collaborative training was on recording technics to prepare the issue of breeding cattle certificate. Collaborative training was assisted by a number of stakeholder facilitators, but, non-collaborative training was carried out by facilitators from an institution. Improvement of farmer technical competency has shown by adding of $58.41 \%$ of cattle population, although there was an increasing of participant cognitive domain by $43.53 \%$ at collaborative training. The recommendation advised that management and keeping cattle technical competency are continiously acquired for the half of groups $(54.5 \%)$, while recording improvement should be taken into account at all groups (100\%).
\end{abstract}

\section{INTRODUCTION}

Stolovitch and Keeps while biotechnological (1992) stated that innovations were very important, their performance depends on the function of human resources competency. Craig (1996) also confirmed that the essence of human resources quality through training program as a determinant factor to group development in a changing environment, biotechnology innovation, economic competition and cultural differences as well as character of each activity.

Then, training is an entry point to anticipate the rapid change as well as social transformation preparedness.

In Indonesia, collaborative training is an important approach due to several reasons. Firstly, liberalization of agricultural extension actor from the state monopoly to private companies as well as farmer groups (see regulation number 16 /2006) admitted three actors of agricultural extension. Secondly, the decentralization of government policy making and the need to accommodate various local conditions to induce agricultural development (Anderson and Hoff, 1993). Finally, West

* Corresponding author.: fmadarisa@gmail.com 
Sumatra's recent approach to agricultural development such as; integrated movement to improve farmer welfare, integrated palm oil estate with keeping cattle, and knowledge based economy. Those indications showed a more competitive advantage than comparative advantage in agricultural development. As Salas et al. (2012) wrote, there are three efforts (finance, products and markets) to achieve competitive advantage. However, within a globalization period, all these three efforts simply to accumulate, except human resource competency. Therefore, a study on 'the collaborative training to improve beef cattle farmer technical competency in West Pasaman district' needs to be done.

The study reconstructed the collaborative training to improve beef cattle farmers' technical competency to support a breeding program improvement in West Pasaman district, in term of planning, conducting and evaluation of training. Then, it was derived into three objectives, namely;

1) To describe the planning of collaborative training to improve beef cattle farmer technical competency.

2) To describe the process of conducting collaborative training to improve beef cattle farmer technical competency.

3) To analyze the outputs and outcomes of collaborative training to improve beef cattle farmer technical competency.

\section{MATERIALS AND METHODS}

The study focused on agricultural education domain (Miller, 2006) which was necessarily designed to human interest with an integrated approach. This approach should integrate 'learning to know, learning to work and learning to be conscious', rejecting a positivism pattern of paradigm (Scoones et al. 2007). In order to fulfill an integrated process all stakeholders should be involved in collecting data and information (Vasstrom, 2007). Two ways of thinking were applied; (1) chronological process of training and its subject implementation and (2) comparing and contrasting between collaborative and noncollaborative training performance.

The evaluation study - in term of outcomes - was conduted at three sub-districts in West Pasaman which were implementing a breeding improvement program for Bali cattle from October to November 2015. Primary data as showed in Table 1; were collected to verify the study objectives. The training process was carried out at UPTD BPPMT Simpang Empat and BPTUHPT Padang Mengatas, 50 Kota, in September to October 2014 for collaborative and non-collaborative training respectively. The secondary data and information were collected to fulfill connected objective.

Sources of information consisted of two categories; training participants and training committees and involving stakeholders. Participants were the main source of information of both types of training who counted by 220 farmers of 22 groups for collaborative training. Then there were 44 farmers of 24 groups for non-collaborative training which consisting of 20 farmers from a main group (Karya Muda) and a farmer from another 23 groups plus a participant from technical specialist candidate. Fifteen persons represented three type of engaged institutions, local provincial and district employers, private business and farmers groups.

There were three steps of information gathering (planning, conducting and evaluation) unit data to verify study objectives. Both primary and secondary data were collected by using indepth-participative interviews, survey questionnaire for primary data and training report, library studies as well as internet access for secondary data. 
Data analysis used a combination between quantitative and qualitative approach (Baker, 2000). A content analysis was also done to provide a more complete results (Bryman, 2006; Giddens, 1991).

Table 1. Unit Data for Supporting the Verification of Study Objectives.

\begin{tabular}{|c|c|c|c|}
\hline No & Planning of Training & Process of Training & Evaluation of Training \\
\hline 1 & Training need analysis & $\begin{array}{l}\text { Conducive environment to } \\
\text { support learning and training } \\
\text { orientation }\end{array}$ & Training outputs \\
\hline 2 & $\begin{array}{l}\text { Design of working mechanism } \\
\text { (location, schedule, budget, subject } \\
\text { matter, and communication method) }\end{array}$ & $\begin{array}{l}\text { Pre-test and technological } \\
\text { support to learn. }\end{array}$ & Training outcomes \\
\hline 3 & Analysis of training participants & $\begin{array}{l}\text { Process and sources of } \\
\text { learning }\end{array}$ & $\begin{array}{l}\text { Feed back to performance } \\
\text { indicators and planning of the } \\
\text { next training }\end{array}$ \\
\hline 4 & Training performance indicators & $\begin{array}{l}\text { Learning practices, game and } \\
\text { simulation }\end{array}$ & - \\
\hline 5 & Participants attendance & Learning and field interaction & - \\
\hline 6 & Training facilitators & Post-test & - \\
\hline 7 & $\begin{array}{c}\text { Commitment of involved parties in } \\
\text { training }\end{array}$ & $\begin{array}{l}\text { Facilities, practical infra- } \\
\text { structure and support systems }\end{array}$ & - \\
\hline
\end{tabular}

\section{RESULTS AND DISCUSSION}

Table 2. Number Population and Farmers Household in West Pasaman

\begin{tabular}{|c|c|c|c|c|c|c|c|c|}
\hline \multirow[t]{2}{*}{ No } & \multirow[t]{2}{*}{ Sub-district } & \multicolumn{3}{|c|}{ Population (person) } & \multirow{2}{*}{$\begin{array}{l}\text { House } \\
\text { hold }\end{array}$} & \multicolumn{3}{|c|}{ Beef cattle household } \\
\hline & & Total & Men & Women & & Cattle & Buflo & Goat \\
\hline 1 & Pasaman & 64.392 & 32.594 & 31.789 & 15.231 & 479 & 51 & 365 \\
\hline 2 & Luhak Nan Duo & 38.318 & 19.301 & 19.017 & 9.126 & 978 & 3 & 156 \\
\hline 3 & Kinali & 62.268 & 31.705 & 30.563 & 14.531 & 1.745 & 58 & 430 \\
\hline 4 & Talamau & 26.500 & 13.319 & 13.181 & 6.108 & 240 & 64 & 105 \\
\hline 5 & Sasak Rnh Pasisie & 13.554 & 6.906 & 6.648 & 3.112 & 537 & 410 & 658 \\
\hline 6 & Gunung Tuleh & 20.809 & 10.343 & 10.466 & 5.144 & 40 & - & 26 \\
\hline 7 & Sungai Aua & 31.596 & 15.977 & 15.619 & 7.621 & 149 & 1 & 160 \\
\hline 8 & Koto Balingka & 26.681 & 13.349 & 13.332 & 6.410 & 97 & 2 & 214 \\
\hline 9 & Lmbh Melintang & 42.943 & 21.171 & 21.772 & 9.507 & 70 & 28 & 56 \\
\hline 10 & Sungai Beremas & 22.888 & 11.724 & 11.164 & 5.041 & 43 & 1 & 134 \\
\hline 11 & Ranah Batahan & 24.054 & 12.092 & 11.962 & 6.052 & 98 & - & 282 \\
\hline \multicolumn{2}{|c|}{ Study Area } & 164.978 & 83.600 & 81.369 & 38.888 & 3.202 & 112 & 951 \\
\hline \multicolumn{2}{|c|}{ Employment } & 160.032 & 100.947 & 59.085 & - & - & - & - \\
\hline \multicolumn{2}{|c|}{ Employment (\%) } & 43 & 54 & 32 & - & - & - & - \\
\hline \multicolumn{2}{|c|}{$\begin{array}{l}\text { Employment Participation } \\
(\%)\end{array}$} & 66.68 & 83.95 & 49.34 & - & - & - & - \\
\hline \multicolumn{2}{|c|}{ Total } & 374.003 & 188.481 & 185.522 & 87.881 & 4.476 & 618 & 2.586 \\
\hline
\end{tabular}

Source: Grand Design of West Pasaman Breeding Program (2014). 
West Pasaman district is one out of four newly created districts after the reformation era in West Sumatra province. As shown in Table 2, the study location could be figured out by twotrends. Firstly, about $71.5 \%$ of beef cattle farmer household stay within location indicating $8.23 \%$ of all household in West Pasaman. However, they are keeping nearly $80 \%$ of cattle population in the district.

Secondly, while population density in the district was 96 person $/ \mathrm{km} 2$, in the three subdistricts its population density reached 158 person/km2. Thus, population density was parallel with cattle density encouraging farmers to keep their cattle within a more intensifiedpattern compatible with breeding program requirement.

Community socio-cultural basis consisted of a various back-ground of ethnics and religions. There was a mixture of native Minangkabau with Mandailing, Javanese and Sundanese transmigration. On such condition, the regional assessment to develop beef cattle business found that there are three types of both government role and level of development. Then, local government could still play all services, regulation and supervision roles, particularly to facilitate breeding program.

\subsection{Planning of Training.}

The mechanism of planning had been translated into terms of reference (ToR) which exposed a consensus among the parties. Based on a training need analysis two co-existence topics should be further developed; institutional capacity building and recording innovation. Both topics were based on the capacity to keep cattle in line with the implementation of modern knowledge and technology.

Budget allocation to support training was prepared by provincial animal production, health and extension services. The training activity was carried out by a private foundation, the Smart
College, which applied a social business and CSR (corporate social responsibility) approach, with the Animal Husbandry Faculty staff as master of training.

Training participants came from farmers' groups which were registered in the breeding development program. They have a commitment to participate in the training by allocating their working hours to it. Facilitators were selected on the merit system basis from the relevant institutions. Budget, time and distance from the host location were taken into account as selection criterion.

UPTD BPPMT Simpang Empat contributed four facilitators on animal feeding. The local districts of West Pasaman sent a number of facilitators on animal health, breeding program, and managing beef cattle in an intensified pattern.

\subsection{Process of Conducting Training.}

Both collaborative and non-collaborative training had been carried out on September to October 2014 at UPTD BPPMT Simpang Empat and BPTUHPT Padang Mengatas respectively. Collaborative training was designed to fulfill the participant needs in order to solve their current problems on keeping beef cattle in line with their groups. Conducive situation was created as flexible as possible to set the experience as a source of learning in lieu of theirs.

A series of activities has been done smoothly from opening ceremony; pre-test; personal introduction and learning contract; and an introduction to breeding program. Insight of the participant hopes and worries was also turned out as learning to transform participants socioeconomic condition by using biotechnological innovation in keeping beef cattle. There were two points of consensus among participants to further discuss; technical competency to keep beef cattle and managing groups in line with breeding program.

* Corresponding author.: fmadarisa@gmail.com 
Then, a further series of activity was a game on groups understanding, effort to increase consciousness of groups member and dynamics, communication within a group and management of keeping beef cattle.

After reviewing the attained results of the first day, participants continued to learn about marketing of their agricultural products as well as animal products. The results showed that participants dominantly argued on the 'price taker' dilemma among their market transaction. Participants also worked together within their group member to plan group activities after training. This was followed by several topics such as; leadership style and impacts; animal feeding; animal health and diseases prevention; introduction to recording schemes; post-test and finally closing ceremony.

\subsection{Training Evaluation.}

Evaluation of training outputs showed that there was an increasing by $43.73 \%$ of participant cognitive domain in collaborative training, although there was 8.18 participants involved only in one post-test, due to their come late. Other output was groups planning after training which should be followed in the field. Participants planning consisted of planting highly quality grass in lieu of usual grass harvesting around their garden. Then, participants committed to improve groups administration in order to consistently support breeding program requirement to yield out breeding certificate. As shown in Table 3 outcomes of collaborative and non-collaborative training simply offereed a different results.

These outcomes could be traced back to the depth discussion results, shown as the following scripting quote;

Recommendation on the colum 5 and 6 were the outcome of collaborative training. Colum 7 was taken from BPTUHPT Padang
Mengatas report on non-collaborative training on November 2015. Then BPTUHPT also developed assessment criterion, such as $\mathrm{A}=$ excellent; B = very good with little improvement effort; $\mathrm{C}=$ minus with major improvement effort.

"Alhamdulillah, setelah kami kembangkan rumput dari UPTD (Simpang Empat), kelompok kami tidak kebingungan untuk mencari rumput dikala musim hujan; mengambil rumput semakin dekat dan dalam waktu yang tidak lama. Jadi, bisa menghemat waktu cari rumput" (Saiyo Sakato; Kinali).

Thank God, after we have been developing high quality grass seed from UPTD, our group does not necessarily misunderstand to find out grass in a rainy season; its closer to pick up grass within a shorter period of time. So, it saves time.

"Dulu mencari rumput ke kebun kebun orang, sekarang ngak usah repot2, karna tinggal ngarit aja dan waktunya lebih singkat" (Lembah Saiyo; Pasaman).

Formally, we found out grass in other people garden, nowadays it is not difficult to gather grass.

"Sekarang, setiap rumput yang habis diambil, tidak langsung diberikan keternak, tapi dikeringkan dahulu, untuk menghilangkan cacing" (Bima Simental; Luhak Nan Duo).

Now, after cutting grass we do not directly serve to animal, but we postpone to do so, in order preventing worm disease.

The management of cattle manure also showed an improved results such as; buidling special location to protect manure from direct water at rainy season; more active to clean cattle building; preventing cattle diseases; and directly reporting diseases to the animal health services.

Administration improvement to support breeding program came from a number of 40.93 $\%$ groups as Juma $(2005 ; 2011)$ confirmed that the performance of biotechnological innovation must be co-existenced with institutional capacity 
effort. The rise of cattle population as to 58.41 $\%$, clearly showed the increasing of technical competency of training participants as they practiced a good breeding activities.

"lebih semangat untuk merawat sapi, menjaga kebersihan, dan lebih terciptanya hubungan sesama anggota. Ada keterbukaannya antara pengurus dan anggota, sehingga anggota dapat mengetahui semua pemasukan dan pengeluaran kelompok" (Bima Simental, Pujo Rahayu, Luhak Nan Duo).

Its now we are more motivated to keep beef cattle due to an increasing transparency among groups members, so we could understand either both groups budget input and output.
Collaborative training put forward the participant experience as a good teacher and the source of learning. This was called by an andragogy approach (Knowles, 1973). Noncollaborative training used both the transfer of knowledge and stick and carrot approaches. In fact, participants were adult who need an adult learning approach.

As we compared and contrast between recording innovation and technical competency on keeping beef cattle, as APL (1982) supported, participant would prefer to adopt an innovation that formerly has grounded basis within the experience. Then recording was totally a new subject disseminated to the participants.

Tabel 3. Outcomes of Collaborative and Non-Collaborative Training

\begin{tabular}{|c|c|c|c|c|c|c|c|c|}
\hline \multirow[b]{2}{*}{ No } & \multirow[b]{2}{*}{ Groups Name } & \multicolumn{2}{|c|}{ Cattle (head) } & \multicolumn{3}{|c|}{ Improvement Recommendation } & \multirow[b]{2}{*}{ Mating } & \multirow[b]{2}{*}{ Value } \\
\hline & & Dec 13 & Oct 15 & Feed & Mgt of group & Recording & & \\
\hline 1 & Margo Makmur & 46 & 78 & - & - & $\mathrm{Y}$ & Mixed & A \\
\hline 2 & Tunas Harapan & 54 & 34 & $\mathrm{Y}$ & $\mathrm{Y}$ & $\mathrm{Y}$ & $\mathrm{AI}$ & $\mathrm{B}$ \\
\hline 3 & Bima Simental & 44 & 60 & - & - & $\mathrm{Y}$ & Mixed & $\mathrm{A}$ \\
\hline 4 & Sejahtera 2 & 43 & 71 & - & - & $\mathrm{Y}$ & Mixed & $\mathrm{A}$ \\
\hline 5 & Mekar Baru & 26 & 39 & - & $\mathrm{Y}$ & $\mathrm{Y}$ & Mixed & $\mathrm{B}$ \\
\hline 6 & Sumber Rejeki & 25 & 46 & - & - & $\mathrm{Y}$ & Mixed & $\mathrm{A}$ \\
\hline 7 & Cinta Makmur & 24 & 40 & - & - & $\mathrm{Y}$ & Bull & $\mathrm{A}$ \\
\hline 8 & Saiyo Sakato & 25 & 83 & - & - & $\mathrm{Y}$ & Mixed & $\mathrm{A}$ \\
\hline 9 & Bina Mitra & 52 & 67 & $\mathrm{Y}$ & - & $\mathrm{Y}$ & Mixed & $\mathrm{B}$ \\
\hline 10 & Karya Baru & 51 & 67 & - & - & $\mathrm{Y}$ & AI & $\mathrm{A}$ \\
\hline 11 & Berkah Bersama & 50 & 94 & - & $\mathrm{Y}$ & $\mathrm{Y}$ & Bull & $\mathrm{C}$ \\
\hline 12 & Lembah Saiyo & 54 & 97 & - & $\mathrm{Y}$ & $\mathrm{Y}$ & Bull & $\mathrm{B}$ \\
\hline 13 & Maju Karya & 55 & 72 & - & $\mathrm{Y}$ & $\mathrm{Y}$ & Bull & $\mathrm{B}$ \\
\hline 14 & Mekar Sari & 51 & 81 & $\mathrm{Y}$ & - & $\mathrm{Y}$ & Mixed & $\mathrm{B}$ \\
\hline 15 & Sinar Terang & 48 & 83 & - & $\mathrm{Y}$ & $\mathrm{Y}$ & Mixed & $\mathrm{C}$ \\
\hline 16 & Sri Mulyo 2 & 58 & 77 & - & - & $\mathrm{Y}$ & Mixed & $\mathrm{A}$ \\
\hline 17 & Makmur & 34 & 56 & $\mathrm{Y}$ & - & $\mathrm{Y}$ & Bull & $\mathrm{B}$ \\
\hline 18 & Setia Kawan & 34 & 62 & - & $\mathrm{Y}$ & $\mathrm{Y}$ & Bull & $\mathrm{B}$ \\
\hline 19 & Setia Karya & 34 & 64 & - & - & $\mathrm{Y}$ & Mixed & $\mathrm{A}$ \\
\hline 20 & Tunas Muda & 54 & 70 & - & $\mathrm{Y}$ & $\mathrm{Y}$ & Mixed & $\mathrm{C}$ \\
\hline 21 & Family Saiyo & 58 & 81 & $\mathrm{Y}$ & $\mathrm{Y}$ & $\mathrm{Y}$ & Bull & $\mathrm{B}$ \\
\hline 22 & Lubuk Gadang & 30 & 61 & - & - & $\mathrm{Y}$ & Mixed & $\mathrm{A}$ \\
\hline \multicolumn{2}{|c|}{ Sub/Rataan/ (\%) } & $950 / 43$ & \multicolumn{3}{|c|}{$1.483 / 67 /(56,1 \%)$} & & & \\
\hline 23 & Karya Muda & 56 & 108 & \# & $\#$ & $\mathrm{Y}$ & Bull & $\mathrm{A}+$ \\
\hline 24 & Tjg Keramat & 35 & 58 & $\#$ & $\#$ & $\mathrm{Y}$ & Bull & $\mathrm{A}$ \\
\hline \multirow{3}{*}{\multicolumn{2}{|c|}{$\begin{array}{l}\text { Sub-total } \\
\text { Total /rataan } \\
\text { Kenaikan }(\%)\end{array}$}} & 91 & 166 & & & & & \\
\hline & & $1041 / 43$ & 1.64 & & & & & \\
\hline & & & $(58,4$ & & & & & \\
\hline
\end{tabular}

Source: Calculated from primary data and reports (2015) Notes: (Y= yes); (- = maintained); (\# = na). 


\subsection{Feed back to the Planning of Training}

Feed-back to improve the next training planning in line with implementation of knowledge and technology in keeping beef cattle should be directed to fulfill the gap of farmer technical competency. Firstly, there should be always kept a conducive learning among farmer groups (Chambers, 2007) particularly in the topics of animal feeding; building maintenance; disease prevention and group administrative support.

Secondly, due to it was not all group success to achieve the objectives, groups development should be directed to special expert on certain products, such as; breeding and manure management. However, as Kusumastanto (2008) stated, farmers should maintain their comprehensive and integrated view on their business. Thirdly, as conducive situation always be maintained, then groups should be facilitated into a competitive effort to prove their performance (Korten 1980; 1984 dan Bank Dunia, 2006; 2012).

Finally, to anticipate an ending of collaborative facilitation from outsiders, groups association should improve their capacity to coordinate the involved parties in a standardized product, as well as a formally contractual basis for their agri-business.

\section{CONCLUSION}

The results of study could be concluded as follow; the planning of training could be traced back to fulfill the gap of technical competency among beef cattle farmers who participate in an improvement of breeding program for Bali cattle. It was not only 24 beef cattle farmers

\section{REFERENCES}

2006. Undang Undang nomor 16 tahun 2006. tentang Sistem Penyuluhan Pertanian, Perikanan dan Kehutanan. Lembaran Negara Republik Indonesia tahun 2006 nomor 92, tambahan lembaran Negara Republik Indonesia nomor 4660. groups participating in collaborative effort, but also followed by Indonesian Bank (BI) West Sumatra representative, BPTUHPT Padang Mengatas, the Animal Husbandry Faculty of the Andalas University, the West Sumatra Animal Health Services, private company and West Pasaman District institutions' role on animal health services.

The process of conducting training focused on farmers' group management and keeping beef cattle technical capacity as well as recordings to prepare the issue of breeding cattle certificate. Collaborative training was assisted by a number of stakeholder facilitators, but, non-collaborative training was only carried out by facilitators from an institution.

Training evaluation resulted an increasing of participant cognitive domain by $43.53 \%$ at collaborative training. Level of participants' satisfaction (affective) on the change of both cognitive and psychomotor domain of noncollaborative training was at $90.15 \%$ and 91.67 $\%$ respectively. Improvement of farmer technical competency has shown by adding of $58.41 \%$ of cattle population. This figure is significantly satisfied due to dominantly decreasing number of cattle population in the government assisted program. The recommendation advised that recording improvement should be taken into account at all groups (100\%), but management and keeping beef cattle technical competency are acquired for the half of groups $(54.5 \%)$ for noncollaborative and collaborative training respectively
Pembibitan Sapi di Kabupaten Terpilih
Pasaman Barat. Yayasan Smart College.
Padang.
Kelompok dan Teknis Peternakan, Program
Penguatan Perbibitan di Kabupaten Terpilih

* Corresponding author.: fmadarisa@gmail.com 
Pasaman Barat. Yayasan Smart College. Padang.

---------, 2015. Laporan Evaluasi dan Monitoring Implementasi Good Breeding Practices (BGP) di Kelompok Pembibitan Sapi Pasaman Barat. BPTUHPT Padang Mengatas

---------, 2015. Evaluasi Program Kerja Tahun 2015 dan Penyusunan Program Kerja 2016. Program Pengembangan Klaster Pembibitan Sapi di Pasaman Barat. Bank Indonesia Perwakilan Sumatera Barat, Padang.

Anderson, J dan K. Hoff. 1993. Technological Change, Imperfect Markets and Agricultural Extension: An Overview, dalam. Hoff, K; A Braverman dan J Stiglitz (ed). The Economics of Rural Organization: Theory, Practice and Policy. World Bank dan Oxford University. Oxford.

Asosiasi Pemandu Latihan (APL), 1982. Petunjuk Dasar Untuk Pemandu. Divisi Produksi. Indonesian Society for Andragogy. Jakarta.

Baker, J. 2000. Evaluating the Impact of Development Projects on Poverty. A Handbook for Practitioners. The World Bank. Washington, D.C.

Bank Dunia, 2006. Enhancing Agricultural Innovation: How to Go Beyond the Strengthening of Research Systems. Economic and Sector Work. The World Bank, Washington.

Bryman, A. 2006. Integrating Quantitative and Qualitative Research: How is it Done? Qualitative Research. Vol. 6(1) 97-113

Chambers, R. 2007. From PRA to PLA and Pluralism: Practice and Theory. IDS Working Paper 286. First published by the Institute of Development Studies in July 2007. Institute of Development Studies 2007. Brighton.

Craig, R. 1996. The ASTD Training and Development Handbook: A Guide to Human Resource Development, 4th edition. McGraw Hill. New York.

Giddens, A. 1991. Sociology. Polity Press. London.
Juma, C. 2005. Biotechnology in a Globalizing World: The Coevolution of Technology and Social Institutions. BioScience: Vol. 55, No. 3 , pp. 265-272.

Juma, C. 2011. The New Harvest: Agricultural Innovation in Africa. Oxford University Press. New York.

Knowles, M. 1973. The Adult Learner: A Neglected Species. American Society for Training and Development, Madison Gulf Publishing Company, Houston.

Korten, D. 1980. Community Organization and Rural Development: A Learning Process Approach. Public Administration Review. September/October 1980; 480-511.

Korten, D. 1984. Rural Development Programming: The Learning Process Approach. dalam Korten, D dan R Klauss. 1984. People-Centered Development: Contributions toward Theory and Planning Frameworks. Kumarian Press, Connecticut.

Kraiger, K; D McLinden dan W Casper. 2004. Collaborative Planning for Training Impact. Human Resource Management, Winter 2004, Vol. 43, No. 4, hal. 337-351.

Kusumastanto, T dkk. 2008. Pemikiran Guru Besar IPB: Perspektif Ilmu Ilmu Pertanian dalam Pembangunan Nasional. Penebar Swadaya dan IPB Press. Jakarta.

Lai, E. 2011. Collaboration: A Literature Review. Always Learning, Pearson Research Report. http://www.pearsonassessment .com/research.

Miller, L. 2006. A Philosophical Framework for Agricultural Education Research. Journal of Agricultural Education; Vol. 47, Number 2, 106-117.

Paudel, N; H. Ojha dan S Rana. 2010. Capacity Building Needs Assessment and Training Strategies for Grassroots REDD Stakeholders in Nepal. RECOFTC - The Center for People and Forests. Bangkok.

Salas, E; S. Tannenbaum; K. Kraiger dan K. Jentsch. 2012. The Science of Training and Development in Organizations: What 
Matters in Practice. Psychological Science in the Public Interest 13(2) $74-101$.

Scoones, I; J Thompson dan R Chambers. 2007. Farmer First: Retrospect and Prospect: Reflections on the Changing Dynamics of Farmer Innovation in Agricultural Research and Development. in Preparation for the Farmer First Revisited Workshop. IDS, University of Sussex 12-14 December 2007.

Stolovitch, H dan E Keeps. ed. (1992). Handbook of Human Performance Technology. Jossey-Bass Publishers. San Francisco.

Taylor, $\mathrm{P}$ dan $\mathrm{J}$ Beniest. 2003. Training in Agroforestry: A Toolkit for Trainers. The
World Agroforestry Centre, United Nations Avenue. Nairobi.

Vasstrom, M. 2007. Facilitating Agricultural Innovation and Learning - a Systemic Action Research Approach. Master Thesis. Norwegian University of Life Science.

World Bank, 2012. Agricultural innovation systems: An investment sourcebook. International Bank for Reconstruction and Development / International Development Association or The World Bank. Washington. 